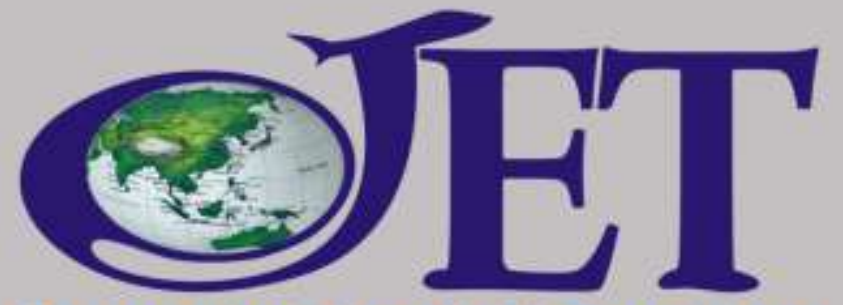

Journal of English Teaching

ISSN 20809628

a

triammual

publication

on the study of

English Language Teaching

Volume 2, Number 3, October 2012

\title{
Blended Learning for ELT
}

\author{
Parlindungan Pardede \\ parlpard2010@gmail.com \\ Universitas Kristen Indonesia
}

\begin{abstract}
Information and communication technology (ICT) has grown exponentially during the past three decades considerably changed many aspects in industrial and trading sectors. Currently, it is revolutionizing education. One of the most important results of the revolution is the emergent of blended learning, which combines the best of face-to-face and ICT application. This article reviews current ideas, practices, and empirical information concerning the nature of blended learning in general and Computer Assisted Language Learning (CALL), a version of blended learning particularly used in English Language Teaching (ELT), in particular. All of these will hopefully enrich creative ideas for implementing blended learning in ELT to enhance our student's achievement.
\end{abstract}

Keywords: ICT, blended learning, CALL, ELT 


\section{Introduction}

Information and communication technology (ICT) has grown exponentially during the past three decades, leading to drastic changes in industrial and trading sectors, and now it is revolutionizing education. Innovations in ICT are expanding the range of possible solutions that can improve teaching and learning inputs, processes, and outcomes. Through the internet access, ICT now offers abundant devices for developing and delivering audio-visual products, multimedia presentations, visual materials and end-user software which could be easily applied to create new learning and teaching practices. Those tools have made it possible to prepare a varied learning environment which will address to students' individual differences. Multimedia and network technology has made it possible for students to learn information anytime and anywhere. Since the on-line data are rich, flexible, and easy to be accepted by the learners, network provides students with an open, realistic language environment (Shen, 2004). Riley (2000) stressed that teaching and learning that use technology effectively can lead to greater academic achievement and make a real difference.

The implementation of ICT in the teaching and learning processes opened the way for new and innovative methods of teaching and learning. One of the most popular methods is called blended learning. This method, which is also called "hybrid learning" and includes any combination of learning delivery methods, including most often face-to-face instruction with asynchronous and/or synchronous computer technologies, has attracted many researchers and educators due to its great potential to maximize the best advantages of face-to-face learning and ICT to deliver learning. It is now becoming the major trend of training in corporate, government, military, and non-profit organizations all over the world. Thorne (2003) claims that blended learning could be one of the most important educational advances of this century since it improves students' learning experience by developing their capacity for reflection (Cooner, 2010) and enables students to become more involved in the learning process (Wang, Shen, Novak, \& Pan, 2009).

This article aims to introduce and enrich our understanding about blended learning. To achieve the objective, current ideas, practices, and empirical information concerning the nature of blended learning derived from emergent literature are reviewed. Discussion begins with the meaning, elements, significances, and current practices of blended learning in education sector in general. After that, discussion is focused on current ideas, practices, and research findings on the implementation of Computer Assisted Language Learning (CALL), a version of blended learning particularly used in English Language Teaching (ELT). All of these will hopefully enrich creative ideas for implementing blended learning in ELT to boost our student's achievement. 


\section{What is blended learning?}

Since blended learning, emerged in the beginning of the $21^{\text {st }}$ century, was essentially based on e-learning, a discussion directed to understand the nature of blended learning could probably commenced by perceiving the meaning of elearning. Various concepts had actually been attributed to e-learning. That is why it is named with various terms, such as computer-based learning, technology-based training, and computer-based training and, therefore, is defined in various definitions. According to Horton (2006), e-learning is "the use of information and computer technologies to create learning experiences" (p.1), while Ellis, Ginns, \& Piggott (2009) define it as "information and communication technologies used to support students to improve their learning". A more detailed definition was offered by Stockley $(2003$, p. 1) who suggests that e-learning is "the delivery of a learning, training or education program by electronic means. E-learning involves the use of a computer or electronic device (e.g. a mobile phone) in some way to provide training, educational or learning material." Koohang \& Harman (2005) state, "E-learning is the delivery of education (all activities relevant to instructing, teaching, and learning) through various electronic media". Another definition states, "E-learning is the use of technology to deliver learning and training programs" (E-learning portal, 2009).

Taking those definitions into consideration, it is obvious that they are different one to another as a consequence of the different elements they focus on. Some emphasize on the use of technology, and some others focus on its use as the delivery-system of education. Despite these differences, all these definitions indicate that e-learning makes it possible for learners to freely access, formulate, organize, and create experiences through the use of information and communication technologies.

Although e-learning soon got many supporters since its emergent in the 1990s, it began to lose its credibility due to many reasons. Some of the most notable reasons are: (1) Students tend to get isolated; many of them give up the course early; (2) Facing the computer all the time does not motivate students for learning very much; (3) Communication tools are provided, but it's up to each student to actually use them; lack of communication naturally produces dropouts; (4) Teachers get too busy and too tired with online material development and individual caretaking online; (5) Students don't get chances to learn from "real" experiences such as lab experiments, guided exercises, and social interactions with classmates; and (6) Information infrastructure is not the same with every student; this could create unfairness (Harashima, n.d.). These oppositions to e-learning stimulated educators and researchers to devise a new concept called "blended learning." This new concept was essentially invented not by totally replacing e-learning but by adding necessary elements to it.

Like many advances in educational practice, blended learning is defined and implemented in multiple ways. As more and more educators and institutions use it, many different meanings have evolved. Singh and Reed (2001) define blended 
learning as "a learning program where more than one delivery mode is being used with the objective of optimizing the learning outcome and cost of program delivery" According to Reay (2001), blended learning is a blend of online and face-to-face instruction. For Neumeier (2005) it is a combination of face-to-face (F2F) and computer assisted learning (CAL) in a single teaching and learning environment. Smith (2001) defined blended learning as "A method of educating at a distance that uses technology (high-tech, such as television and the Internet or low-tech, such as voice mail or conference calls) combined with traditional (or, stand-up) education or training. In line with this, Bonk and Graham (2006, p. 5) states "Blended learning systems combine face-to-face instruction with computer-mediated instruction." Another definition emphasizes that blended learning "blends online learning with more traditional methods of learning and development" ("Thorne, 2003, p. 2).

Although there are a wide variety of definitions of blended learning, most of the definitions in the literature are just variations of a few common themes. Based on literature review, Graham, Allen, and Ure, (as cited in Bonk and Graham (2003, p.4) found three most commonly mentioned definitions of blended learning: (1) blending instructional modalities (or delivery media), (2) blending instructional methods, and (3) blending online and face-to-face instruction. According to Bonk and Graham, the first two defines blended learning so broadly that they encompass virtually all learning systems. Isn't it very difficult to find any learning system that does not involve multiple instructional methods, instructional technology and delivery media? So defining blended learning in either of these two ways waters down the definition and does not get at the essence of what blended learning is and why it is exciting to so many people. The third definition, which emphasizes on the blend of online and face-to-face instruction, more accurately reflects the historical emergence of blended learning systems.

The third definition above, which "takes the best of both worlds and creates an improved learning experience for the student" (Elearnspace, 2005), is considered the most common interpretation at the present day. Friesen (2012) accentuated that from 2006 to the present, blended learning has been understood as a combination of face-to face and technology-mediated instructional forms and practices. This is in line with most currently proposed definitions. Garrison \& Vaughan (2008: p. 42), for instance, emphasize that "The basic principle of blended learning is that face-to-face oral communication and online written communication are optimally integrated such that the strengths of each are blended into a unique learning experience congruent with the context and intended educational purpose." Koohang (2009) accentuates that blended learning is "a mix of traditional face-to-face instruction and e-learning." Watson $(2008$, p.4) states that blended learning combines online delivery of educational content with the best features of classroom interaction and live instruction to personalize learning, allow thoughtful reflection, and differentiate instruction from student to student across a diverse group of learners. 
Table 1: Types of Courses

\begin{tabular}{|c|c|c|}
\hline $\begin{array}{l}\text { Proportion of } \\
\text { Content } \\
\text { Delivered } \\
\text { Online }\end{array}$ & $\begin{array}{l}\text { Type of } \\
\text { Course }\end{array}$ & Typical Description \\
\hline $0 \%$ & Traditional & $\begin{array}{l}\text { Course with no online technology used-content } \\
\text { is delivered in writing or orally. }\end{array}$ \\
\hline 1 to $29 \%$ & $\begin{array}{l}\text { Web } \\
\text { Facilitated }\end{array}$ & $\begin{array}{l}\text { Course, which uses Web-based technology to } \\
\text { facilitate what is essentially a face-to-face course. } \\
\text { Uses a course management system (CMS) or Web } \\
\text { pages to post the syllabus and assignments, for } \\
\text { example. }\end{array}$ \\
\hline 30 to $79 \%$ & Blended & $\begin{array}{l}\text { Course that blends online and face-to-face } \\
\text { delivery. Substantial proportion of the content is } \\
\text { delivered online, typically uses online discussions, } \\
\text { and typically has some face-to face meetings. }\end{array}$ \\
\hline$\geq 80 \%$ & Online & $\begin{array}{l}\text { A course where most or all of the content is } \\
\text { delivered online. Typically have no face-to-face } \\
\text { meetings. }\end{array}$ \\
\hline
\end{tabular}

Allen, Seaman, and Garrett's (2007, p. 5)

It is now clear that blended learning combines face-to-face and the Internetbased technologies. But can any course that includes these two elements called blended learning? According to Allen, Seaman, and Garrett's $(2007$, p. 5) to be called blended learning, 30 to $79 \%$ of a course's content should be delivered through ICTs. They presented the table above to illustrate the prototypical course classifications and the proportions of online parts of the different learning and teaching environments.

\section{The Benefits of Blended Learning}

Since blended learning combines the best of face-to-face instruction and computer-mediated instruction, it provides many benefits. Osguthorpe \& Graham (cited in Bonk \& Graham, 2006, pp. 8-10) identified six potential benefits blended learning can offer. First, blended learning presents pedagogical richness. Some blended learning systems, for instances, are designed to let learners go through three phases, i.e. (1) online self-paced learning to acquire background information, (2) face-to-face learning lab focused on active learning and application experiences instead of lecture, and (3) online learning and support for transferring the learning to the workplace environment. Second, blended learning opens access to knowledge. Third, blended learning facilitates social interaction. Fourth, blended learning facilitates personal agency. Fifth, blended learning offers cost-effectiveness and 
provides an opportunity for reaching a large, globally dispersed audience in a short period of time with consistent, semi personal content delivery. In the practical level, by moving part of face-to-face learning to blended learning, travel expenses can be reduced, and by moving some of media-rich content to face-to-face learning, the cost for material development and infrastructure rigging can be reduced. Finally, blended learning provides ease of revision.

In addition to these six items, other the results of researches offer the following benefits of blended learning implementation. First, blended learning allows teaching to continue when schools close (Riel and Paul, 2009). Second, students become active learners. They can communicate their needs and interests to their teachers to become more successful (Pape, 2006). Third, blended learning can alleviate the negative effect of poorly designed online programs with high quality instructor led sessions (Mackay and Stockport, 2006).

\section{Blended Learning in English Teaching}

Since blended learning has provided education with many benefits and has innumerable potentials to discover, it must be very potential to enhance language education. The application of various types of ICT to learning and teaching foreign languages is not something totally new (see for example, Davies, 2000; Kenning, 2008; and Shelly, 2000). Tape recorders and videos are two products of technology that language teachers have included to optimize their face to face teaching for decades. The emergence of ICT has provided teachers with immense opportunities for including new educational resources and tools.

In this regard, the application of computer-assisted language learning (CALL) in ELT is essentially a blended learning, because it blends information and computer technology applications with face-to-face teaching and learning. Through the internet, English teachers can get a wide array of teaching materials and tools that meet the needs of their unique teaching situations. These include texts, audiotapes with accompanying workbooks, videotapes with student worksheets, and various CALL programs for teleconferencing and asynchronously or synchronously delivered activities, and so on. Some of them are designed for teaching general English while some others are for teaching reading, writing, speaking, listening, grammar, vocabulary-building, cross-cultural communication, pronunciation, English for specific purposes, TOEFL preparation, etc. Many of the materials are also accompanied with motivating and interesting activities. These activities could be done alone or interactively by students and teachers or by one student with other students in the classroom or from different places. The combination of ICT with face-to-face learning as described above will surely enrich the learning materials and extend the learners' scope of interaction from the student-teacher and student-student interaction to the computer-based interactive activities. At the same time, it extends the ways of communication from the face-to-face interaction to the communication via electronic means. 
The application of blended learning does essentially not reject face to face learning, but rather enhance its possibilities. Let's illustrate this using the following scenario. In the classroom, the teacher uses the main materials (slides and texts) in printing. To make the class more enjoyable, the teacher can also get relevant audio and video from the internet. He then asks the students to access additional materials from certain Internet links. Since the internet is a gigantic repository of learning materials, each student can find and study materials of his own choice online. By doing this, the teacher provides a more individualized learning experience. Then, students can be assigned to do quiz or exercise online. These can support audio, video, and animations, and some interactive features such as drag and drop matching, order sequencing, and identifying points and areas on images.

Finishing the face-to-face session in the classroom, communication may proceed through the internet. Using webinar, teachers and students can also have virtual classroom, in which they have classes without being physically present in the classroom. Besides that, various devices, like chat, forum, and Skype are available to facilitate online communication. The communication could be conducted synchronously (face to face) or asynchronously (through text). Online discussion forum enables the participants to interact using different styles of discussion and interaction. In addition, the asynchronous forums provide environments where normally reticent participants can contribute more. To a certain extent, such forums provide the students with less stressful practice environment for the target language, so that every student will be engaged in the learning process. In addition, since the discussions are asynchronous, they allow time for participants to reflect on their ideas, do further reading and research, and give more informed and considered responses. By doing so, the students are provided a place to learn and practice the target language beyond the classroom, and thereby increasing contact hours. Constructionism holds that people create new knowledge and learn most effectively through social interaction and exchanging information for the benefits of others (Burr, 2003).

Finally, the teacher can design and set tests and exams, which may also be automatically marked and feedback and/or to correct answers shown. The possibility for the teacher and peers to give feedback on a student's work will enable him to get more personalized learning support. In addition, the interactive forums will encourage every student to be independent and collaborative as well.

Although the teaching scenario above is very simple, it reveals some blended learning powerful potentials teachers will not find in the face-to-face traditional instruction alone. use to succeed their language classrooms. In relation to this, Marsh (2012, p. 4-5) list nine strengths of blended language learning: (1) provides a more individualized learning experience; (2) provides more personalized learning support; (3) supports and encourages independent and collaborative learning; (4) increases student engagement in learning; (5) accommodates a variety of learning styles; (6) provides a place to practice the target language beyond the classroom; (7) provides a 
less stressful practice environment for the target language; (8) provides flexible study, anytime or anywhere, to meet learners' needs; (9) helps students develop valuable and necessary twenty-first century learning skills.

\section{Some Current Studies on ELT Blended Learning}

Bijeikienè, Rašinskienė, Zutkiene's (2011) research revealed that English language teachers display a generally positive attitude towards blended learning. The teachers to a large extent agree about the efficiency of the blended learning courses in terms of the resources contained there, such as video lectures, theory presentations, interactive exercises for self-check and others. However, they express some doubts with regard to the usefulness of the activities in the virtual environment, such as virtual consultations and discussions, which can again be related to their need to improve their overall ICT-awareness. It can also be related to the fact that the young generation of students embraces technological progress more naturally than most of the teachers. Alseweed' (2013) research results indicate that there are significant differences among the instructional approaches in the achievement test scores in favor of blended learning. In addition, the results show significant differences in students' attitudes in favor of blended learning.

The study of Liu et al. (2002) proved the positive effects of computer technology in second language learning. It reinforced the findings of Dunkel (1990) which noted that computers increased "the language learner's self-esteem" as well as their academic skills (Cited in: Liu et al., 2002). Chun \& Brandl (1992) mentioned that providing immediate feedback for students while they study the course is a computer's advantage. Ehsani \& Knodr (as cited in Liu, 2002) think that using computer technology in second language learning enhances the ability to speak in the second language.

YouTube is one of the effective educational tools EFL teachers can use in their blended learning, because it provides exposure to authentic English as well as the promotion of a learning style that is more autonomous and student-centered. It displays a wide variety of user-generated content, video content, including movie clips, television clips and music videos as well as amateur content such as video blogging and short original videos which are most immediately observed through sight and sound, creative teachers can easily find new ways to use them in listening and speaking or English conversation classes. Another important benefit of using YouTube is that when students regularly use a wide variety of English media, they are achieving a degree of English immersion that might otherwise be unavailable outside a study-abroad program (Johnson \& Swain, 1997).

An effective and interesting activity EFL teachers can conduct in the classrooms by using materials from YouTube is karaoke. This activity involves songs, a combination of music and lyrics which possesses many intrinsic merits, such as a cultural kaleidoscope, expressiveness, recitability and therapeutic functions, which render it an invaluable source for language teaching. Karaoke is activity really 
highly motivational helpful for developing listening, speaking (including phonemes, stress, linking, and rhythms exercises), grammar, vocabulary, cultural understanding. To tech grammar for instance, teachers can use Eric Clapton's Wonderful Tonight for teaching the simple present tense, Rod Stewart's Sailing for present continuous tense, Cat Stevens' Morning Has Broken for present perfect, Simon and Garfunkel's El Condor Pasa for conditionals, and so on. To teach vocabulary, Louis Armstrong's What a Wonderful World is very effective for words of colors and Buddy Holly's Raining in my Heart for words of the weather.

Another advantage offered by karaoke is that it is also adaptable and teachers can vary the speed, the context (pictures), the presentation and even have students record. To make the activity more fun, the teacher can vary the ways the students sing. For instance, the teacher can turn off the sound and get students to "read" or "sing" and keep up with the words/script. The teacher can also divide the class into groups and give each group one line of the chorus and when it comes up "the group" sings their line. This is effective and doesn't single out students. In selecting the songs for karaoke, the teacher should try to ensure about four things. First, the songs' lyrics are clear and volume is audible. Secondly, the vocabulary is appropriate for the proficiency level. Third, the songs are age appropriate. Finally, the songs are prescreened for contents (avoid songs with inappropriate religious allusions, racial indications and sexual references).

One of the most effective the Internet tools EFL teachers can utilize to develop their students' writing skills is blogs. Several studies (e.g. Sun, 2009 and Lee, 2010) reported that integrating digital technologies, namely blogs, in the classroom to develop writing skills foster a sense of collaboration and community, develop a sense of voice and foster critical and analytical skills. The results of Arani's (2005) study on the use of blogs to develop writing, reading and communication skills in English for Specific Purposes among non-native speakers of English at Kashan University of Medical Sciences in Iran revealed that students preferred to write on the weblog than the traditional ways, and weblogs can improve English in the context of ESP. These findings are in line with Pardede's (2011) study on student teachers' interest and perception on the use of BALL (Blog Assisted Language Learning) as an additional component in writing skills development in Christian University of Indonesia. The study revealed that a majority of the respondents basically viewed the use of BALL to develop writing interesting and effective. More than a half of them admitted they wrote more productively after joining BALL. The internet facilities (authentic articles and writing manuals) they could easily access while writing in the blog were very helpful to produce good writing. They also used fellow students' works as a 'mirror' to prevent errors. The greatest motivating factor for the respondents in writing in the blog is their realization that their works were visible to many people in the world. This awareness motivated them to check word choice and spelling more carefully. 
Another effective educational tool ELT teacher could use in the classroom to develop students' writing skills is Wiki. Franco (2008) tested Wikis for lowintermediate level EFL instruction with students in a private language school in Brazil. The data were collected from two sources: wiki submissions and responses to an online questionnaire containing eight multiple-choice questions. The Wiki was used for peer correction, in a group setting. The results suggested positive perceptions of wiki activity. The pre-/post-peer correction data indicated progress in language acquisition.

In a study conducted by Engstrom and Jewtt (2005), students were organized into groups of four to six students to make the wiki web pages manageable. Results showed that the participated students expressed satisfaction with their learning. They indicated that they had the most positive experience. The participated teachers also pointed out that their technology knowledge and skills improved after the project and that most students became independent about their learning.

Mohammed's (2010) experimental study conducted to investigate the effect of using wikis to develop 30 fourth-year prospective English as a Foreign Language (EFL) teachers' writing performance in Egypt revealed the effectiveness of using wikis in developing prospective EFL teachers' writing performance. This was shown by findings that statistically significant differences were found between the mean scores of the experimental group and the control group on the post-WPT in favor of the experimental group.

Khoii and Arabsarhangi's (2009) study aimed at investigating the effect of wikis' collaborative environment on the improvement of Iranian EFL learners' writing skill revealed similar result with Mohammed's. The participants of this study, 60 students within the age of 14-16 chosen on the basis of a homogenizing proficiency test, were divided into one control and two experimental groups, each with 20 students. Collaboration was the key concept in both experimental groups, where the members wrote through collaborative work and were corrected by their peers. While the activities in one of the experimental groups were done in the wiki environment, those in the other experimental group were performed in the class following the norms of any collaboration-oriented class. The students in the control group wrote individually and were corrected by the teacher. The same materials were used for teaching writing in all the three classes, and the same teacher taught them. After the 2- month treatment period, the same topic was given to all the participants to write a composition, each on their own. The results of an analysis of variance revealed that collaboration in the wiki environment produced a better student.

Chuan Lin and Ching Yang (2011) conducted a study to explore students' perceptions of integrating Wiki technology and peer feedback into an English writing course among 32 sophomore students in an English department at a college in Taiwan. The researchers used a socio-cultural theoretical framework to explore students' perceptions of the effectiveness of wiki-based writing projects and experiences of social interaction in the process of writing, based on self-reported 
reflections about the project, observations of student learning, interviews and surveys. The study revealed that most students felt positive about their ability to apply Wiki and peer feedback to writing instruction. Nevertheless, students encountered both functional and psychological obstacles to using the new tools; indicating the need to change their traditional learning practices to follow new technology- enhanced learning systems.

Usluel, Mazman and Arikan (2009) investigated ELT student teachers' awareness of collaborative web 2.0 tools in Turkey. Focusing specifically on wikis, blogs and podcasts in language learning, the study concluded that prospective teachers are not mostly aware of web 2.0 tools that can be used in language learning. However, it became clear that pre-service language teachers need training in using Internet applications for language learning/teaching purposes.

\section{Conclusions}

Most EFL teachers will agree that students do not have opportunities to practice the skills and language components they just learned in different and varied contexts due to the limited time they have in the classroom. Various current studies revealed that blended learning systems could effectively tackle this problem. Blended learning provides EFL students with recording devices, video players, newspapers, and language laboratories. A variety of activity types with group work and pair work, collaborative learning and independent learning could be employed to engage the learners in communicative language practice. In addition, the inclusion of the online element in blended learning also enables the use of the foreign language in real communicative acts (through forums, chats, emails, etc.) and provides students with authentic learning material. What's more, it allows for the diversity of EFL students' learning styles to be catered for, perhaps more easily than in face-to-face settings.

\section{References}

Allen, I. E., Seaman, J., \& Garrett, R. (2007). Blending in: The extent and promise of blended education in the United States. Needham, MA: Sloan Consortium. Retrieved from http://sloanconsortium.org/sites/default/files/Blending_In.pdf Alonso, F., López, G., Manrique, D., \& Viñes, J. M. (2005). An instructional model for web-based e-learning education with a blended learning process approach. British Journal of Educational Technology, 36(2), 217-235.

Alsewed, M.A. (2013). Students' achievement and attitudes toward using traditional learning, blended learning, and virtual classes learning in teaching and learning at the university level. Studies in Literature and Language 6/1, 2013, pp. 65-73

Arani, J. A. (2005). Teaching writing and reading English in ESP through a webbased communicative medium: Weblog. ESP-world 4 (3).

Bath, D. and Bourke, J. (2010). Getting started with blended learning. Griffith Institute for Higher Education. Retrieved from: www.griffith.edu.au/gihe 
Bijeikiene, Rasinskiene, Zutkiene's (2011). Teachers' attitudes towards the use of blended learning in general English classroom. Studies About Languages, 18, 122-127.

Bonk, C.J. and Graham, C. R. (Eds) (2006). The handbook of blended learning. Pfeiffer, San Francisco.

Burr, V. (2003). Social constructionism ( $2^{\text {nd }}$ ed.). London: Routledge.

Chun, D., \& Brandl, K. K. (1992). Beyond form-based drill and practice: Meaning enhancing CALL on the Macintosh. Foreign Language Annals, 25(3), 255265.

Chuan Lin, W. and Ching Yang, S. (2011). Exploring Students' Perceptions of Integrating Wiki Technology and Peer Feedback into English Writing Course. English Teaching: Practice and Critique 10/2. Retrieved June 12, 2012, from: http://education .waikato .ac. nz/ res earch/files/etpc/files/2011v10n2dial1.pdf

Cooner, T. S. (2010). Creating opportunities for students in large cohorts to reflect in and on practice: lessons learnt from a formative evaluation of students' experiences of a technology-enhanced blended learning design. British Journal of Educational Technology, 41(2), 271-286.

Davies, G., 2000. CALL (computer assisted language learning). In Routledge Encyclopedia of Language Teaching and Learning, Byram, M. (ed.), London: Routledge, pp.90-93.

Dunkel, P. (1990). Implications of the CAI effectiveness research for limited English proficient learners. Computers in the Schools, 7(1/2), 31-52.

E-learning Portal (2009). E-learning glossary. Retrieved October 7, 2010, from http://www.e-learningguru.com/glossary/e.htm.

Elearnspace (2005). Blended. Retrieved March 21, 2010, from http://www. elearnspace.org/doing/blended.htm

Ellis, R. A., Ginns, P., \& Piggott, L. (2009). E-learning in higher education: Some key aspects and their relationship to approaches to study. Higher Education Research \& Development, 28(3), 303. Retrieved January 18, 2011, from: http://www.informaworld.com/10.1080/07294360902839909

Engstrom, M., \& Jewett, D. (2005). Collaborative learning the wiki way. TechTrends: Linking Research and Practice to Improve Learning. 49 (6), 12-16.

Fleming, N., and Baume, D. (2006). Learning styles again: VARKing up the right tree! Educational Developments, SEDA Ltd, Issue 7.4, Nov. 2006, p.4-7.

Franco, C.D.P. (2008). Using wiki-based peer-correction to develop writing skills of Brazilian EFL learners. Novitas-ROYAL, 2 (1), 49-59. Retrieved March 20, 2010, from: http://www.novitasroyal.org/franco.pdf

Friesen, N. (2012). Report: Defining blended learning. Retrieved September 7, 2012, from: http://learningspaces.org/papers/Defining_Blended_Learning_NF.pdf 
Garrison, D.R. \& Vaughan, N. (2008). Blended learning in higher education: Framework, principles, and guidelines. San Francisco: Jossey-Bass.

Harashima, H.D. (n.d.) Blended Learning: where it came from and where it heads to. Retrieved July 30, 2012 from: http://glocall.org/pluginfile.php/1300/ mod_resource/content/0/Blended_Learning.pdf

Horton, W. (2006). E-Learning By-design. San Francisco: John Wiley \& Son

Johnson, R. K., \& Swain, M. (1997). Immersion education: International perspectives. Cambridge: Cambridge University Press.

Khoii, R. and Arabsarhangi, Z. (2009). The effect of wikis' collaborative environment on the improvement of Iranian EFL learners' writing skill. Retrieved May 11, 2011, from: :www.pixel-online.net/.../IEC07-56-FPArabsarhangi..pdf .

Koohang, A. (2009). A learner-centered model for blended learning design. International Journal of Innovation and Learning, 6(1), 76-91.

Koohang, A., \& Harman, K. (2005). Open source: A metaphor for e-learning. Informing Science Journal, 8, 75-86.

Kenning, M., 2008. ICT and language learning: From print to the mobile phone. New York: Palgrave Macmillan.

Lee, L. (2010). Fostering reflective writing and interactive exchange through blogging in an advanced language course. ReCALL, 22(2), 212-227.

Liu, M., Moore, Z., Graham, L., \& Lee, S. (2002). A look at the research on computer-based technology use in second language learning: a review of literature from 1990-2000. Journal of Research on Technology in Education, 34 (3), 250-273; ProQuest Education Journals.

Mackay, S. \& Stockport, G.J. (2006). "Blended Learning, Classroom and ELearning." Business Review, Cambridge, 5:1, September 2006.

Marsh, D. (2012). Blended learning: Creating learning opportunities for language learners. Cambridge: Cambridge University Press.

Mohammed, M.M.K. (2010). Using wikis to develop writing performance among prospective English as a foreign language teachers. Retrieved May 25, 2011, from: www.nauss.edu.sa/acit/PDFs/f1766.pdf

Neumeier, P. (2005). A closer look at blended learning: Parameters for designing a blended learning environment for language teaching and learning. ReCALL 17(2), 163-178.

Osguthorpe, R.T. \& Graham, C.R. (2003). Blended learning environments, definitions and directions. The Quarterly Review of Distance Education, 4(3), 227233.

Pape, L., Sheehan, T., \& Worrell, C. (2012, April). How to do more or less: lessons from online learning. Learning \& Leading with Technology. Retrieved May 9, 2012, from http://go.galegroup.com.ezproxy.liberty.edu:2048/ ps/i.do?id:=GALEA $28284109 \& \mathrm{cv}=2.1 \& \mathrm{cu}$ 
Pardede, P. (2011). Using BALL to develop writing skills: Students' interest and perception. Paper presented at SWCU international Conference 2011 held in Satya Wacana Christian University, Salatiga, November 2011.

Reay, J. (2001). Blended learning - a fusion for the future. Knowledge Management Review, 4(3), 6.

Riel, M. \& Paul, S. (2009). "Collaborative Knowledge Building: Blending In-Class and Online Learning Formats." Distance Learning, 6:3, 2009. Retrieved September 9, 2010, from http://search.proquest.com/socialsciences/docview/230717922/ 1315DECB46B34CC8663/

Riley, R. (2000). Intel ${ }^{\circledR}$ Teach to the Future Brings Together Microsoft and Other Industry Leaders in Half-Billion Dollar Commitment to Improve Student Learning. Retrieved on March 14, 2009 from: http://www.intel.de/press room/archive /releases/ed012000.htm

Shelly, M., 2000. Distance learning. In Routledge Encyclopedia of Language Teaching and Learning, Byram, M. (ed.), London: Routledge, pp.183-185.

Shen Y. Q. (2004)."The possibilities of teaching online English extensive reading in English major", Journal of Yulin Teachers College, 4, pp.108-110.

Singh, H., \& Reed, C. (2001). A white paper: Achieving success with blended learning. Centra Software. Retrieved July 12, 2010, from http://www.centra.com/ download/whitepapers/blendedlearning.pdf.

Stockley, D. (2003). E-learning definition and explanation (Elearning, Online Training, Online Learning). Retrieved July 14, 2010, from: http://derekstockley. com.au/elearning-definition.html?

Sun, Y. C. (2009). Voice blog: An exploratory study of language learning. Language Learning \& Technology, 13(2), 88-103. Retrieved, March 25, 2011, from: http://lt.msu.edu/vol13num2/sun.pdf

Thorne, K. (2003). Blended learning: How to integrate online and traditional learning. London: Kogan Page.

Usluel, Y. K., Mazman, S. G., \& Arikan, A. (2009). Prospective teachers' awareness of collaborative web 2.0 tools. The IADIS International Conference WWW/Internet 2009.

Wang, M., Shen, R., Novak, D., \& Pan, X. (2009). The impact of mobile learning on students' learning behaviours and performance: report from a large blended classroom. British Journal of Educational Technology, 40(4), 673-695.

Watson, J. (2008). Blended learning: The convergence of online and face-to-face education. The North American Council for Online Learning. Retrieved July 14, 2010, from: http://www.inacol.org/research/ promisingpractices/NACOL_PP-BlendedLearning-lr.pdf 